\title{
The Roles and Performance of Professional Driving Instructors in Novice Driver Education
}

"Zulhaidi M. Jawi, ${ }^{1}$ Baba M. Deros, ${ }^{2}$ Ahmad A. A. Rashid, ${ }^{1}$ Mohd H. M. Isa, ${ }^{1}$ Azmi Awang ${ }^{3}$

$$
\text { أدوار وأداء مدربي القيادة المهنية في تعليم السائق المبتدى }
$$

$$
\text { زولهادي محمد جاوي، بابا ديروس، أحمد أزاد أبو راش،، محمد حفظي محمد عيسى، عزمي أوانغ }
$$

ABSTRACT: This review article aimed to analyse existing literature regarding the roles and performance of professional driving instructors (PDIs) in novice driver education (DE). A systematic classification scheme was adopted to analyse identified articles to determine the study context of PDIs in novice DE, the competency level of PDIs in relation to experienced and learner drivers and the contributions of PDIs to the novice driver learning process. A total of 14 original research articles were identified, with no systematic reviews or meta-analyses available. Overall, all of the articles were found to be inadequate in providing an in-depth understanding of the roles and performance of PDIs in novice DE. There is an urgent need to improve current understanding of the roles of PDIs in novice DE and to work towards an internationally recognised PDI management approach.

Keywords: Public Health Systems Research; Safety; Accident Prevention; Automobile Driving; Automobile Driver Examination.

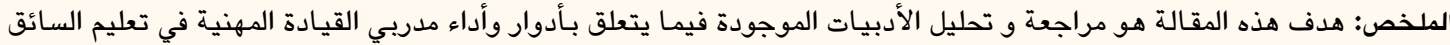

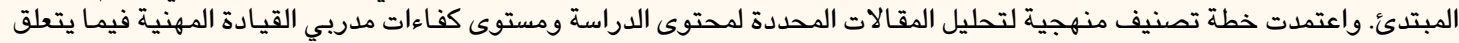

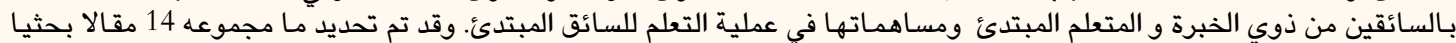

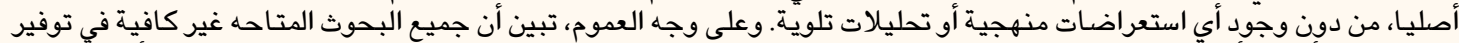

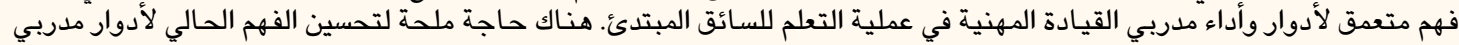

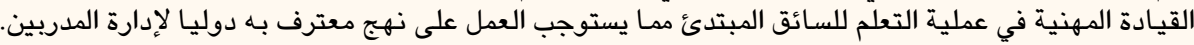

$$
\begin{aligned}
& \text { الكلمات المفتاحية: بحوث نظم الصحة العامة؛ السلامة؛ الوقاية من الحوادث؛ قيادة السيارات؛ فحص سائق السيارات. }
\end{aligned}
$$

$\mathrm{D}$ RIVING IS AN INSTRUMENTAL ACTIVITY of daily living; however, it can be extremely dangerous as even a minor mistake can result in complicated and life-threatening injuries or death. ${ }^{1,2}$ According to the World Health Organisation, the number of global road traffic fatalities exceeded one million in recent years, with another 20-50 million people either injured or incapacitated due to road traffic accidents. ${ }^{2}$ In particular, young and novice drivers constitute the highest proportion of road traffic accident victims. ${ }^{2,3}$ In acknowledgement of this problem, the United Nations has instituted a Decade of Action for Road Safety framework, with the aim of reducing worldwide road traffic fatalities by $2020.2,4,5$ This framework highlights graduated driver licensing (GDL) as an activity that strengthens the process of licensing road users, reflecting the importance of maintaining procedures to ensure that only effective drivers enter the road system. ${ }^{2,6}$ The pre-licence learning-to-drive phase is important for new drivers to overcome issues associated with inexperience, gain exposure to road traffic rules, train their basic manoeuvring and vehicle handling skills and learn to recognise hazards. ${ }^{7}$ In GDL, for example, additional curfew restrictions can also address immaturity issues in novice drivers and serve to eliminate external influences which can lead to road traffic accidents. ${ }^{6}$

Every country has a different set of regulations for driver licensing, at either the national or regional level, as well as its own unique philosophy and approach to driving. ${ }^{78}$ For example, differences exist in the minimum age permitted to start the licensing process; the training approach (including the number of required training hours and final assessment type); and various restrictions prior to full licensing., The GDL licensing process is divided into learner, intermediate/provisional and full license stages. ${ }^{6}$ In the first stage, learner drivers (LDs) must obtain practical driving experience in a low-risk environment with guidance from a more experienced driver. ${ }^{6}$ In the intermediate stage, LDs are subject to restrictions on nighttime driving, driving with passengers and alcohol 


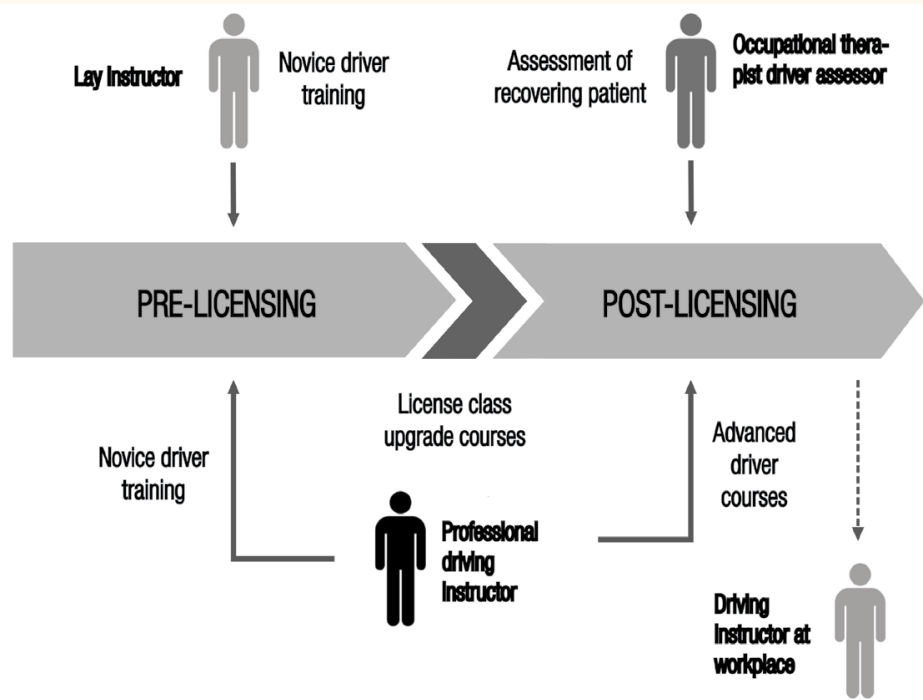

Figure 1: Overview of the roles of various personnel, particularly professional driving instructors, in both pre- and postlicensure driver education.

consumption. Only after passing these two stages do LDs progress to full licensure. ${ }^{6}$ In countries that do not utilise a GDL system, these first two phases are usually combined, resulting in only pre-and full license stages; LDs usually need to complete off- and on-road training activities, including classroom lessons, theory tests and on-track and on-road driving sessions before undergoing a practical driving test. In Malaysia, for example, the pre-licensing phase is similar to the GDL system with a two-year probationary status for new drivers; however, Malaysia neither refers to these two years as a GDL period nor follows the stricter GDL scheme implemented by other countries such as New Zealand, Australia, the USA or Canada. ${ }^{6,10}$

Within the pre-licensing stage, the training process can either be informal or formal. ${ }^{11}$ With the formal approach, candidate drivers study a standardised driving curriculum and complete a certain number of training hours before taking a final test. These activities are usually handled by commercial driving schools with the involvement of professional driving instructors (PDIs) who work within an approved or accredited legislative scope of the government usually in a business or occupational framework (i.e. a driving school or institute). ${ }^{10}$ In contrast, the informal approach acknowledges the eligibility of parents, family members or other adults to act as driving trainers-as any method adopted to ensure the ability of LDs to drive and pass the test is considered valid-even though such instructors may be outside of the established driver education (DE) system. These so-called lay instructors are sometimes referred to as private instructors or supervisors. ${ }^{12,13}$ They normally conduct informal training to help novice drivers meet the required number of supervised driving hours as part of a supervised behind-the-wheel practice scheme. For many novice drivers, the use of lay instructors is more affordable than enrolling in a commercial driving school. ${ }^{13}$

Regardless of the system on which it is based, novice DE should focus on three elements: the goals of the education, the educational content and the process/test. ${ }^{14}$ Previous researchers have studied the goals for DE and their application in a licensing system. ${ }^{15,16}$ However, the approach to DE instruction is as critical as its content and assessment; central to the delivery of DE content is the PDI, sometimes also referred to as a DE instructor or approved driving instructor. ${ }^{17,18}$ Additionally, PDIs may be involved in the post-licensing stage, for example when drivers wish to upgrade their license class so as to operate heavy (i.e. lorries), recreational (i.e. all-terrain vehicles) or public transport (i.e. buses and taxis) vehicles. Qualified PDIs may also offer advanced courses that emphasise valueadded driving skills such as driving in hazardous or emergency situations, nocturnal or eco-driving and off-roading, occupational specialist training to drive hearses and limousines or introductory lessons to new crash avoidance or advanced braking technologies. Other post-licensing driver trainers include driving instructors either fully or partially in the service of private or government institutions (such as ambulatory services in hospitals) or occupational therapist driver assessors/certified driver rehabilitation specialists for patients recovering from certain illnesses. ${ }^{1,19}$ Figure 1 provides an overview of the various personnel involved in both pre- and post-licensure DE and training.

The roles and performance of the PDI in the novice DE environment are particularly important since the PDI remains with the LD from their first 


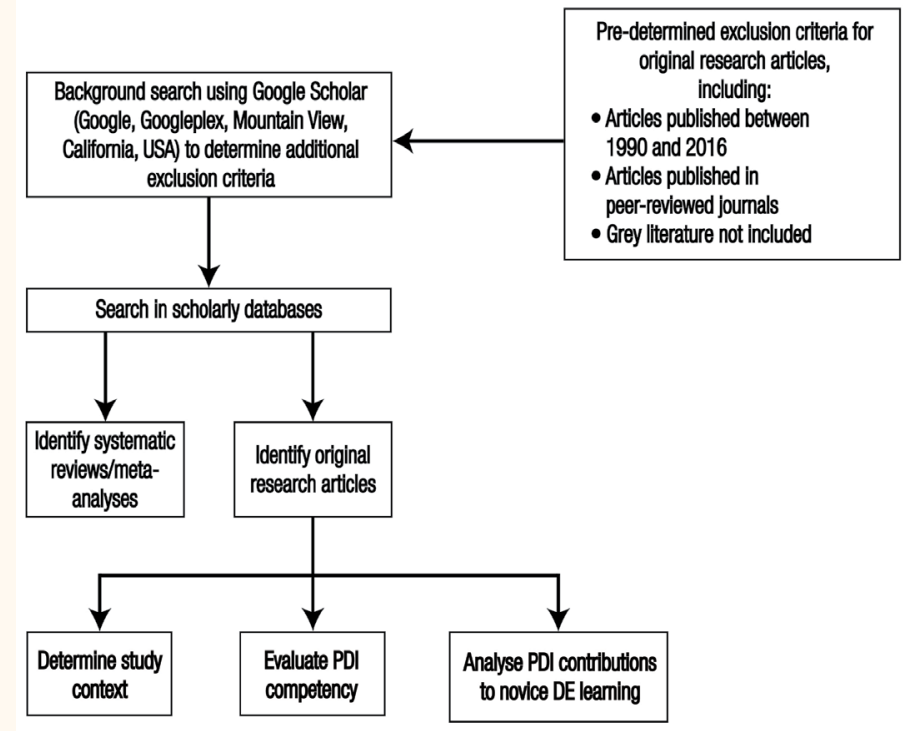

Figure 2: Diagram illustrating the search strategy used to identify literature related to the roles and performance of professional driving instructors in novice driver education.

$P D I=$ professional driving instructor; $D E=$ driver education .

lesson until the final assessment, which usually takes the form of a practical driving test. While previous research has examined the responsibility involved in training novice drivers, few studies have focused on the specific contributions of PDIs. This review therefore aimed to analyse existing literature regarding the roles and performance of PDIs in novice DE.

\section{Methods}

This review was performed in January 2017. The search strategy comprised an initial background search of Google Scholar (Google, Googleplex, Mountain View, California, USA) followed by an investigation of systematic reviews/meta-analyses and original research articles included in scholarly databases [Figure 2]. In the initial background search, there were 22,500 results for the keywords "driver training", 19,400 for "driver education", 9,360 for "driver licensing", 4,570 for "driving instructor" and 320 for "driver instructor". However, the majority of these articles were related to medical fields, including studies of occupational therapist driver assessors or associations between driving and illnesses such as dementia; stroke; Parkinson's disease; visual impairment; neurological conditions; orthopaedic issues; sleep problems; attention deficit hyperactivity disorder (ADHD); autism spectrum disorder (ASD); Down's syndrome; and the effect of drugs, medications and alcohol. ${ }^{20-28}$ The subject population was often composed of older drivers, with the articles focusing on their fitness to drive. Critically, even if PDIs were involved in some articles, they were not the main subjects but were instead contributors, for instance in upholding the research design or its validity and reliability. ${ }^{29}$ Therefore, these articles were excluded from the final analysis.

Subsequently, the second and third steps of the review methodology involved searching scholarly databases for systematic reviews/meta-analyses and original research articles. All searches were performed using the keywords "driving instructor" and "driver instructor" and were limited to accessible databases such as ScienceDirect (Elsevier, Amsterdam, the Netherlands), MEDLINE ${ }^{\circledR}$ (National Library of Medicine, Bethesda, Maryland, USA), the Cochrane Library (Cochrane, London, England, UK), Inderscience Publishers (Geneva, Switzerland), the Wiley Online Library (John Wiley \& Sons Inc., Hoboken, New Jersey, USA), Taylor \& Francis Online (Milton Park, Oxfordshire, UK) and Emerald eJournals (Emerald Group Publishing, Bingley, West Yorkshire, UK). The researchers' expert knowledge of the subject of DE contributed extensively to building the search mechanism and strategy; for example, as most articles on DE and driver licensing originate from the USA, Australia and Europe, searches were often focused on publications originating from these regions ${ }^{6,8,9}$

For original research articles, a systematic classification scheme was adopted based on previous research published by Lage et al. and Hachicha et al. and adapted by other researchers, including OviedoTrespalacios et al..$^{30-32}$ Accordingly, each original research article was examined using a systematic classification scheme to determine (1) the article's context with regards to PDIs in novice DE, including 
Table 1: Literature review of original research articles related to the roles and performance of professional driving instructors in novice driver education ${ }^{16,17,27,33-43}$

\begin{tabular}{|c|c|c|c|c|c|}
\hline \multirow[t]{2}{*}{ Author and year of study } & \multirow[t]{2}{*}{ Methods } & \multirow{2}{*}{$\begin{array}{l}\text { PDI position } \\
\text { in study }\end{array}$} & \multicolumn{2}{|c|}{$\mathbf{N}$} & \multirow{2}{*}{$\begin{array}{l}\text { Type of } \\
\text { results }\end{array}$} \\
\hline & & & PDI sample & LD sample & \\
\hline Almberg et al..$^{27}(2017)^{*}$ & $\begin{array}{l}\text { Interviews and } \\
\text { questionnaires }\end{array}$ & $\begin{array}{l}\text { Secondary } \\
\text { sample }^{\dagger}\end{array}$ & 9 & $\begin{array}{c}33 \text { LDs with } \\
\text { ADHD or ASD }\end{array}$ & $\begin{array}{c}\text { Quantitative } \\
\text { and } \\
\text { qualitative }\end{array}$ \\
\hline Roelofs et al..$^{35}$ (2015) & $\begin{array}{l}\text { Psychometric } \\
\text { analyses from } \\
\text { an examination } \\
\text { database }\end{array}$ & Sample & $\begin{array}{l}4,741 \text { prospective } \\
\text { PDIs }\end{array}$ & - & Quantitative \\
\hline Austers et al..$^{38}$ (2015) & Questionnaires & $\begin{array}{l}\text { Comparative } \\
\text { sample }\end{array}$ & 32 & $\begin{array}{l}400 \text { EDs (152 in } \\
\text { study } 1 \text { and } 248 \text { in } \\
\text { study } 2)\end{array}$ & Quantitative \\
\hline Boccara et al. ${ }^{41}(2015)$ & $\begin{array}{l}\text { Longitudinal } \\
\text { analyses }\end{array}$ & $\begin{array}{l}\text { Dyadic } \\
\text { sample }\end{array}$ & \multicolumn{2}{|c|}{ 4. PDI-LD dyads } & Quantitative \\
\hline Molina et al. ${ }^{16}$ (2014) & Interviews & Sample & 676 & - & Quantitative \\
\hline De Stefani et al. ${ }^{43}$ (2014) & $\begin{array}{l}\text { Video-recording } \\
\text { corpus }\end{array}$ & $\begin{array}{l}\text { Non- } \\
\text { comparative } \\
\text { sample }\end{array}$ & 2 & 7 & Qualitative \\
\hline Arnau-Sabatés et al. ${ }^{36}$ (2012) & Questionnaires & Sample & 177 future PDIs & - & Quantitative \\
\hline Passmore et al..$^{17}$ (2011) & Interviews & Sample & 15 & - & Qualitative \\
\hline Boccara et al..$^{34}(2011)^{\ddagger}$ & Questionnaires & $\begin{array}{l}\text { Secondary } \\
\text { sample }^{\dagger}\end{array}$ & 38 & 150 & Quantitative \\
\hline Boccara et al..$^{33}(2011)^{\ddagger}$ & Questionnaires & $\begin{array}{l}\text { Comparative } \\
\text { sample }\end{array}$ & 38 & 149 & Quantitative \\
\hline Rismark et al. ${ }^{42}(2007)$ & $\begin{array}{c}\text { Interviews and } \\
\text { observation }\end{array}$ & $\begin{array}{l}\text { Non- } \\
\text { comparative } \\
\text { sample }\end{array}$ & 51 & 191 & Qualitative \\
\hline Lajunen et al. ${ }^{37}$ (2003) & Questionnaires & $\begin{array}{l}\text { Comparative } \\
\text { sample }\end{array}$ & $\begin{array}{l}47 \text { applicant } \\
\text { PDIs }\end{array}$ & 54 & Quantitative \\
\hline Treffner et al. ${ }^{39}(2002)$ & Instrumented cars & $\begin{array}{l}\text { Comparative } \\
\text { sample }\end{array}$ & 4 & $\begin{array}{l}9 \text { EDs (5 in study } 1 \\
\text { and } 4 \text { in study } 2 \text { ) }\end{array}$ & Quantitative \\
\hline Katila et al. ${ }^{40}(1996)$ & Questionnaires & $\begin{array}{l}\text { Comparative } \\
\text { sample }\end{array}$ & 108 & 382 & Quantitative \\
\hline
\end{tabular}

$P D I=$ professional driving instructor $\angle D=$ learner driver $; A D H D=$ attention deficit hyperactivity disorder; $A S D=$ autism spectrum disorder; EDs = experienced drivers.

*First published online in July 2015.

${ }^{\dagger}$ The researchers collected data on/from PDIs but placed very little emphasis on the results or discussions of the PDI sample as compared to the LD sample.

${ }^{\text {*}}$ The same samples were discussed in two separate articles.

the research methodology, type of analysis and the PDI's position of involvement in the study; (2) the competency of PDIs in comparison to other experienced or LDs; and (3) the contribution of PDIs to the learning process (i.e. the influence of the PDI on the novice driver's performance). In order to ensure quality, the scope of the review included only articles published between 1990-2016 in peer-reviewed journals. Grey literature was not considered suitable for analysis, although it was used to gain insights into the topic. Unlike medical research articles, which normally have extensive, descriptive titles that highlight the health issues covered, articles related to PDI at the novice driver level were found to have less explicit titles which required close scrutiny of the abstract, keywords and main text of the articles.

\section{Results and Discussion}

Neither systematic reviews nor meta-analyses relating to PDIs at the novice DE level were found during the literature research, indicating a scarcity of research on this topic. However, a total of 14 original research articles were identified from 10 countries, including Sweden, the Netherlands, Latvia, France, Spain, Switzerland, the UK, Norway, Finland and Australia. ${ }^{16,17,27,33-43}$ The most common data collection tools were questionnaires and interviews. Other 
Table 2: Literature review of original research articles placing less emphasis on professional driving instructors' roles and performance in novice driver education ${ }^{27,34-37}$

\begin{tabular}{|c|c|c|c|c|}
\hline $\begin{array}{l}\text { Author and } \\
\text { year of study }\end{array}$ & Objective of study & $\begin{array}{l}\text { Type of PDI } \\
\text { sample }\end{array}$ & Results/Discussion & Conclusion \\
\hline $\begin{array}{l}\text { Almberg et al. } .^{27} \\
(2017)^{*}\end{array}$ & $\begin{array}{l}\text { To investigate the } \\
\text { facilitators/barriers to } \\
\text { DE among LDs with } \\
\text { ASD or ADHD from } \\
\text { the perceptive of both } \\
\text { LDs and their PDIs }\end{array}$ & $\begin{array}{l}\text { Secondary } \\
\text { sample }^{\dagger}\end{array}$ & $\begin{array}{l}\text { - LDs with ASD required twice } \\
\text { the number of driving lessons and } \\
\text { more on-road tests than those } \\
\text { with ADHD; translating theory } \\
\text { to practice and adapting to 'new' } \\
\text { driving circumstances were the } \\
\text { most common difficulties for LDs } \\
\text { with ASD. } \\
\text { - LDs with ADHD had to repeat } \\
\text { written tests more often than those } \\
\text { with ASD and found theoretical } \\
\text { concepts challenging. }\end{array}$ & $\begin{array}{l}\text { For LDs with ASD and } \\
\text { ADHD, the licensure } \\
\text { training process was a } \\
\text { stressful experience }\end{array}$ \\
\hline $\begin{array}{l}\text { Boccara et al. }{ }^{34} \\
(2011)\end{array}$ & $\begin{array}{l}\text { To examine LDs' self- } \\
\text { assessment of their } \\
\text { driving capabilities } \\
\text { during DE training }\end{array}$ & $\begin{array}{l}\text { Secondary } \\
\text { sample }^{+}\end{array}$ & $\begin{array}{l}\text { - While men tended to assess } \\
\text { themselves more positively, no } \\
\text { substantial gender difference was } \\
\text { observed at various training stages. } \\
\text { - LDs' self-ratings correlated } \\
\text { negatively with the number of self- } \\
\text { estimated driving hours but did } \\
\text { not differ significantly with PDI } \\
\text { estimates. }\end{array}$ & $\begin{array}{l}\text { LDs' self-assessments } \\
\text { were more positive in } \\
\text { the initial stage of driver } \\
\text { training as compared to } \\
\text { later self-assessments }\end{array}$ \\
\hline $\begin{array}{l}\text { Roelofs et al. }{ }^{35} \\
(2015)\end{array}$ & $\begin{array}{l}\text { To evaluate the } \\
\text { reliability, validity and } \\
\text { fairness of different } \\
\text { versions of theoretical } \\
\text { tests for prospective } \\
\text { PDIs }\end{array}$ & $\begin{array}{c}\text { Specific sample } \\
\text { of prospective } \\
\text { PDIs }\end{array}$ & $\begin{array}{l}\text { - Psychometric analyses showed } \\
\text { that the theory tests resulted in } \\
\text { reliable and fair decisions regarding } \\
\text { PDI certification. } \\
\text { - The predictive validity for PDI } \\
\text { certification was low for theory } \\
\text { tests in the final assessment. }\end{array}$ & $\begin{array}{l}\text { Follow-up studies should } \\
\text { focus on determining } \\
\text { whether improved } \\
\text { PDI examinations will } \\
\text { produce safer drivers }\end{array}$ \\
\hline $\begin{array}{l}\text { Arnau-Sabatés } \\
\text { et al. }{ }^{36}(2012)\end{array}$ & $\begin{array}{l}\text { To analyse the } \\
\text { relationship between } \\
\text { emotional abilities and } \\
\text { drivers' self-reported } \\
\text { risky attitudes }\end{array}$ & $\begin{array}{c}\text { Specific sample } \\
\text { of prospective } \\
\text { PDIs }\end{array}$ & $\begin{array}{l}\text { - Risky attitudes correlated } \\
\text { negatively with emotional abilities. } \\
\text { - Adaptability and interpersonal } \\
\text { abilities were described based on } \\
\text { the global risk attitude index. } \\
\text { - The propensity to take risks was } \\
\text { influenced by stress management } \\
\text { and interpersonal components. } \\
\text { - Emotional abilities had the } \\
\text { weakest relationship with alcohol } \\
\text { and drug use. }\end{array}$ & $\begin{array}{l}\text { Emotional abilities were } \\
\text { important to lessen risky } \\
\text { driving behaviours and } \\
\text { should be stressed in } \\
\text { prevention programmes }\end{array}$ \\
\hline $\begin{array}{l}\text { Lajunen et al. }{ }^{37} \\
(2003)\end{array}$ & $\begin{array}{l}\text { To investigate the } \\
\text { effects of socially } \\
\text { desirable response } \\
\text { tendencies on self- } \\
\text { reports of driving in } \\
\text { public and private } \\
\text { environments }\end{array}$ & $\begin{array}{l}\text { Comparative } \\
\text { samples of } \\
\text { applicant PDIs } \\
\text { and LDs }\end{array}$ & $\begin{array}{l}\text { - Aberrant behaviours were } \\
\text { reported less frequently in public as } \\
\text { compared to private settings. } \\
\text { - Socially desirable response biases } \\
\text { were somewhat decreased in DBQ } \\
\text { responses. }\end{array}$ & $\begin{array}{l}\text { Self-reports of driver } \\
\text { behaviour were fairly } \\
\text { reliable and free from } \\
\text { socially desirable } \\
\text { response bias }\end{array}$ \\
\hline
\end{tabular}

methods included psychometric and longitudinal analyses, a video-recording corpus, instrumented cars and observation. A total of 5,904 PDIs were involved, of which 939 were already qualified while the remaining 4,965 were classified as prospective, future or applicant PDIs. Additionally, a total of 1,230 learner or experienced drivers were involved, of which 33 had ADHD or ASD. ${ }^{27}$ It should be noted that the PDI and LD samples mentioned by Boccara et al. were discussed in two separate articles. ${ }^{33,34}$ In total, 10 of the studies reported quantitative results, three reported qualitative results and one reported results using both approaches [Table 1]. ${ }^{16,17,27,33-43}$
A review of the original research articles revealed seven ways of classifying the roles of PDIs within the study: as secondary samples in relation to LDs; as samples of future/applicant/prospective PDIs; as samples of future/applicant/prospective PDIs in comparison to LDs; as specific samples; as samples compared with experienced or LDs; as non-comparative samples; and as dyadic samples (i.e. including both PDIs and LDs in pairs). ${ }^{16,17,27,33-43}$ The roles of PDIs were deemed non-primary in Almberg et al's and one of Boccara et al.'s studies. . $^{27,34}$ Moreover, Roelofs et al., Arnau-Sabatés et al. and Lajunen et al. each focused on factors outside the 
Table 3: Literature review of original research articles placing more emphasis on professional driving instructors' roles and performance in novice driver education ${ }^{16,17,33,38-43}$

\begin{tabular}{|c|c|c|c|c|}
\hline $\begin{array}{l}\text { Author and year } \\
\text { of study }\end{array}$ & Objective of study & $\begin{array}{l}\text { Type of PDI } \\
\text { sample }\end{array}$ & Results/Discussion & Conclusion \\
\hline $\begin{array}{l}\text { Molina et al. }{ }^{16} \\
(2014)\end{array}$ & $\begin{array}{l}\text { To analyse the } \\
\text { implementation of } \\
\text { a driver training } \\
\text { curriculum using the } \\
\text { GDE framework as } \\
\text { reference }\end{array}$ & $\begin{array}{l}\text { Specific } \\
\text { sample }\end{array}$ & $\begin{array}{l}\text { - A two-factor solution was found to match } \\
\text { the first dimension of the GDE framework; } \\
\text { however, there was no factor differentiation } \\
\text { in the second dimension. } \\
\text { - The curriculum emphasised knowledge and } \\
\text { skills related to operative and tactical aspects } \\
\text { of driving; however, less importance was } \\
\text { placed on risk prevention and self-evaluation } \\
\text { skills at the strategic and personal levels of } \\
\text { driving behaviour. }\end{array}$ & $\begin{array}{l}\text { Potential weaknesses } \\
\text { were identified in the } \\
\text { curriculum as per the } \\
\text { GDE framework; these } \\
\text { potential flaws may } \\
\text { be overcome by the } \\
\text { proper application of } \\
\text { instructional methods } \\
\text { and teaching tools to } \\
\text { correct LD training }\end{array}$ \\
\hline $\begin{array}{l}\text { Passmore et al. }{ }^{17} \\
(2011)\end{array}$ & $\begin{array}{l}\text { To explore the } \\
\text { experiences of qualified } \\
\text { driving instructors (i.e. } \\
\text { ADIs or PDIs) in using } \\
\text { coaching as a method for } \\
\text { novice DE }\end{array}$ & $\begin{array}{l}\text { Specific } \\
\text { sample }\end{array}$ & $\begin{array}{l}\text { - Seven themes were identified: } \\
\text { understanding the nature of coaching; } \\
\text { building an integrated approach; developing } \\
\text { new skills; accepting responsibility for } \\
\text { learning; helping learners to change their } \\
\text { attitudes; performance; and achieving wider } \\
\text { adoption of coaching within the industry. }\end{array}$ & $\begin{array}{l}\text { Coaching has a role to } \\
\text { play in DE }\end{array}$ \\
\hline \multirow[t]{2}{*}{$\begin{array}{l}\text { Austers et al. }{ }^{38} \\
(2015)\end{array}$} & $\begin{array}{l}\text { Study 1: To study the } \\
\text { judgement of EDs and } \\
\text { PDIs in predicting road } \\
\text { accidents based on } \\
\text { traffic rule violations }\end{array}$ & $\begin{array}{l}\text { Comparative } \\
\text { sample with } \\
\text { EDs }\end{array}$ & $\begin{array}{l}\text { There were no differences in ratings of } \\
\text { traffic rules by violators and non-violators. } \\
\text { - However, there were rating differences } \\
\text { between PDIs and violators (i.e. violators } \\
\text { rated speeding as being a less important } \\
\text { factor leading to accidents, whereas driving in } \\
\text { reverse and U-turn rules were deemed more } \\
\text { important). } \\
\text { - PDIs were slightly better than EDs in } \\
\text { predicting accidents based on violations. }\end{array}$ & $\begin{array}{l}\text { PDIs and EDs did not } \\
\text { differ significantly } \\
\text { in their assessments } \\
\text { of 'unwritten' traffic } \\
\text { rules or judgements } \\
\text { that particular traffic } \\
\text { rules can facilitate road } \\
\text { safety }\end{array}$ \\
\hline & $\begin{array}{l}\text { Study 2: To explore EDs' } \\
\text { and PDIs' assessments of } \\
\text { 'unwritten' driving rules } \\
\text { to explain safe versus } \\
\text { risky driving }\end{array}$ & $\begin{array}{l}\text { Comparative } \\
\text { sample with } \\
\text { EDs }\end{array}$ & $\begin{array}{l}\text { - There were some differences in judgments } \\
\text { regarding 'unwritten' driving rules (i.e. PDIs } \\
\text { tended to view driving behaviour negatively). } \\
\text { - No significant differences were detected } \\
\text { between PDIs and EDs in judging 'unwritten' } \\
\text { traffic rules, although some of the judgments } \\
\text { were interesting (i.e. participants reported } \\
\text { that signalling another driver about a police } \\
\text { post facilitated road safety). }\end{array}$ & \\
\hline $\begin{array}{l}\text { Boccara et al. } \\
(2011)\end{array}$ & $\begin{array}{l}\text { To examine the } \\
\text { development of LDs' } \\
\text { self-assessments } \\
\text { compared to PDI } \\
\text { assessments of LD } \\
\text { performance }\end{array}$ & $\begin{array}{l}\text { Comparative } \\
\text { sample with } \\
\text { LDs }\end{array}$ & $\begin{array}{l}\text { - LD self-assessments and PDI ratings } \\
\text { increased positively in relation to all aspects } \\
\text { of the assessment scale as the training } \\
\text { progressed. } \\
\text { - The LDs' and PDIs' ratings did not differ } \\
\text { significantly between each of the three tested } \\
\text { driving situations. } \\
\text { - Similar results were observed between male } \\
\text { and female LDs at each stage of training. } \\
\text { - LDs' overestimation of their driving skills } \\
\text { was mainly observed during step one, less so } \\
\text { during steps two and three and never during } \\
\text { step four. }\end{array}$ & $\begin{array}{l}\text { LDs accurately } \\
\text { assessed their driving } \\
\text { skills as the training } \\
\text { course progressed }\end{array}$ \\
\hline $\begin{array}{l}\text { Treffner et al. }{ }^{39} \\
(2002)\end{array}$ & $\begin{array}{l}\text { Study 1: To examine } \\
\text { whether deceleration } \\
\text { and braking control were } \\
\text { augmented by sensitivity } \\
\text { to perceptual variable } \\
\text { tau based on TTC } \\
\text { Study 2:To measure } \\
\text { supposed differences } \\
\text { in driving behaviour } \\
\text { between EDs and PDIs } \\
\text { during a set of normal } \\
\text { driving manoeuvres }\end{array}$ & $\begin{array}{l}\text { Comparative } \\
\text { sample with } \\
\text { EDs }\end{array}$ & $\begin{array}{l}\text { - PDIs had different cornering paths and } \\
\text { emergency braking strategies; their ability to } \\
\text { perform a high-speed swerve and perform } \\
\text { effectively in the recovery task was higher as } \\
\text { compared to EDs. } \\
\text { - PDIs applied greater bracing forces using } \\
\text { the door and console and greater footrest } \\
\text { forces during emergency braking as } \\
\text { compared to EDs. } \\
\text { - PDIs more frequently braced themselves to } \\
\text { counter g-forces when driving, indicating an } \\
\text { active stabilisation strategy that boosted both } \\
\text { postural stability and overall stability and } \\
\text { consistency. }\end{array}$ & $\begin{array}{l}\text { Training programmes } \\
\text { should concentrate } \\
\text { on increasing } \\
\text { driver stability as } \\
\text { a foundation to } \\
\text { enhancing driver } \\
\text { control while driving, } \\
\text { thereby improving } \\
\text { road safety }\end{array}$ \\
\hline
\end{tabular}




\begin{tabular}{|c|c|c|c|}
\hline $\begin{array}{l}\text { Katila et al. }{ }^{40} \\
(1996)\end{array}$ & $\begin{array}{l}\text { To compare the views } \\
\text { of PDIs and LDs on skid } \\
\text { training courses and why } \\
\text { these special training } \\
\text { courses have failed to } \\
\text { get people to drive more } \\
\text { safely on slippery roads }\end{array}$ & $\begin{array}{l}\text { Comparative } \\
\text { sample with } \\
\text { LDs }\end{array}$ & $\begin{array}{l}\text { - In all of the studied countries (Denmark, } \\
\text { Finland, Norway and Sweden), PDIs' and LDs' } \\
\text { assessments of skid training courses were the } \\
\text { same. } \\
\text { - Upon completion of the training course } \\
\text { by LDs, manoeuvring skills were deemed } \\
\text { more important than anticipating skills even } \\
\text { though the purpose of the training course was } \\
\text { to improve anticipating skills. } \\
\text { - The training courses may have given LDs } \\
\text { the impression that manoeuvring skills were } \\
\text { more vital than anticipating skills. }\end{array}$ \\
\hline $\begin{array}{l}\text { De Stefani et } a l^{43} \\
(2014)\end{array}$ & $\begin{array}{l}\text { To study how PDIs } \\
\text { direct LDs to perform } \\
\text { salient driving actions }\end{array}$ & $\begin{array}{l}\text { Non- } \\
\text { comparative } \\
\text { sample }\end{array}$ & $\begin{array}{l}\text { - Two types of instructions were frequent } \\
\text { during training: navigational and car control/ } \\
\text { traffic check instructions. } \\
\text { - Instructions were frequently given } \\
\text { non-verbally and were highly effective in } \\
\text { producing immediate execution. } \\
\text { - The coordination of time, space, talk and } \\
\text { action during driving lessons was complex as } \\
\text { LDs were required to continuously monitor } \\
\text { events and actions both inside and outside of } \\
\text { the car. }\end{array}$ \\
\hline $\begin{array}{l}\text { Rismark et al. }{ }^{42} \\
(2007)\end{array}$ & $\begin{array}{l}\text { To observe PDI-LD } \\
\text { interactions during } \\
\text { on-road practice and } \\
\text { determine how PDIs } \\
\text { can use dialogue as an } \\
\text { effective learning tool } \\
\text { in DE }\end{array}$ & $\begin{array}{l}\text { Non- } \\
\text { comparative } \\
\text { sample }\end{array}$ & $\begin{array}{l}\text { - During on-road practice, PDI-LD dialogues } \\
\text { created a shared understanding of the full } \\
\text { road traffic situation. } \\
\text { - Different approaches by PDIs led to } \\
\text { intersubjectivity of occurring traffic situations } \\
\text { in qualitatively different ways. } \\
\text { - PDIs practiced both clarifying and } \\
\text { elaborative processes to inculcate responsible } \\
\text { driving. } \\
\text { - The merging of the roles of 'teacher' and } \\
\text { 'learner' laid a foundation for subsequent } \\
\text { scaffolding processes during on-road practice. }\end{array}$ \\
\hline $\begin{array}{l}\text { Boccara et al. }{ }^{41} \\
(2015)\end{array}$ & $\begin{array}{l}\text { To comprehend the } \\
\text { scaffolding activity of } \\
\text { PDIs during driving } \\
\text { lessons in urban traffic }\end{array}$ & $\begin{array}{l}\text { Dyadic sample } \\
\text { with LDs }\end{array}$ & $\begin{array}{l}\text { - PDIs used integrative approaches in the } \\
\text { form of 'cutting' and 'decoupling' during the } \\
\text { learning process as opposed to the step-by- } \\
\text { step method suggested in the curriculum. } \\
\text { - The PDIs transferred responsibility for } \\
\text { driving components to LDs in the following } \\
\text { order: (1) technical manoeuvres; 2) situation } \\
\text { identification; and (3) focusing on other road } \\
\text { users. } \\
\text { - LDs' driving autonomy and efficiency } \\
\text { increased as training progressed; however, } \\
\text { their execution of basic tasks in complex } \\
\text { situations remained uncertain at the end of } \\
\text { the training and PDIs remained dominant } \\
\text { with regards to navigational tasks. }\end{array}$ \\
\hline
\end{tabular}

Manoeuvring exercises increased LDs' selfconfidence and may have influenced LDs to underestimate associated risks of skidding, causing them to drive at higher speeds on slippery roads

Instructional sequences both influence and are influenced by language and social interactions

Further knowledge is still needed to truly determine what makes DE effective in terms of driving behaviours and accident risks

By the end of training, LDs did not independently perform navigational tasks, with PDI navigation interventions increasing as training progressed; in effect, PDIs did not completely uncouple the decision-making process

$P D I=$ professional driving instructor $; G D=$ Goals for Driver Education; $L D=$ learner driver; $A D I=$ approved driving instructor; $D E=$ driver education; $E D=$ experienced driver $; T C=$ time-to-contact

scope of the systematic classification scheme (i.e. the validity of theoretical assessments for PDIs as well as emotional abilities related to self-reported risky driving behaviours and the effects of socially desirable response bias on self-reported driving behaviours). ${ }^{35-37}$ Nonetheless, despite their lack of emphasis on the roles of PDIs in novice DE, these studies provided useful insights into novice DE, including the importance of psychological factors on driving behaviours and selfassessment [Table 2]. ${ }^{27,34-37}$

Table 3 summarises the remaining six original research articles which placed more emphasis on the role of PDIs in novice DE, in which PDI samples were either analysed as a specific sample or compared to experienced or LD samples in terms of driving behaviours or knowledge. ${ }^{16,17,33,38-40}$ Austers et al. found that PDIs and EDs did not differ in their judgement of 'unwritten' traffic rules, with PDIs only slightly better than LDs in predicting traffic violations as causes of accidents. ${ }^{38}$ Moreover, Treffner et al. reported that PDIs performed better than experienced drivers during a variety of everyday driving manoeuvres, particularly with regards to the application of braking and bracing strategies. ${ }^{39}$ While studies by Boccara et al. and Katila et al. were generally focused on the learning process rather than determining the comparative performance of PDIs, the findings of these studies nevertheless suggested that there were skill-specific performance differences between PDIs and LDs; in other words, these two groups were equally competent in certain skills but not others. ${ }^{33,40}$ One potential explanation for this variation is that while some skills can be taught in 
classroom settings, others cannot. For instance, while LDs can learn traffic laws and regulations from books and the Internet, learning to perceive road hazards generally comes only with driving practice, of which PDIs have much more hands-on experience.

In terms of assessing the contributions of PDIs to the learning process, Passmore et al. provided a qualitative assessment of PDIs' perspectives of coaching novice DEs. ${ }^{17}$ Out of the seven themes which emerged from the analysis, several indicated that PDIs did not overly contribute to novice DE, particularly in stressing learner's acceptance of responsibility for their learning or helping learners to change their attitudes. ${ }^{17}$ Another study by Boccara et al. on the PDI-LD training process suggested that PDIs contributed to LD learning even though sometimes the instruction was not delivered according to recommended methods in the curriculum. ${ }^{41}$ The three remaining studies did not fall under the scope of the systematic classification scheme. For example, Molina et al's study focused on the delivery of DE curricula based on the Goals for Driver Education framework, while Rismark et al. and De Stefani et al. addressed language use during driving instruction and social interactions in DE. ${ }^{16,42,43}$

In general, the findings of the literature review reaffirm that very little research has been published internationally with regard to PDI; moreover, the research available is highly dispersed and covers a wide range of subtopics. ${ }^{16}$ More exploration is needed to enrich academic understanding of PDIs' roles and performance and help road safety practitioners reshape or enhance novice DE programmes. In addition, such research would enable related government agencies to implement best practices and correctly position PDIs in the national DE training system. This may eventually lead to the development of an internationally recognised PDI management approach and assessment system.

\section{Conclusion}

This review aimed to assess existing literature on the roles and performance of PDIs in novice DE. Overall, the existing literature was insufficient to provide an in-depth understanding of the influential role of PDIs in DE. Furthermore, with regards to the competency and contribution to the novice driver learning process on the part of the PDI, most identified articles were very diverse and covered many different subtopics. Further research would contribute to a more developed understanding of the role and performance of PDIs; the results of such studies would be useful for future interventions, which might include the implementation of an internationally recognised PDI management approach as well as critical requirements for PDI certifications.

\section{ACKNOWLEDGEMENTS}

The authors greatly appreciate the feedback provided by the anonymous reviewers and editors as part of the peer-review and submission process.

\section{References}

1. Unsworth C, Harries P, Davies M. Using social judgment theory method to examine how experienced occupational therapy driver assessors use information to make fitness-to-drive recommendations. Br J Occup Ther 2015; 78:109-20. doi: 10.1177/ 0308022614562396 .

2. World Health Organization. Global status report on road safety 2015. From: www.who.int/violence_injury_prevention/road_ safety_status/2015/en/ Accessed: Jun 2017.

3. Scott-Parker B, Watson B, King MJ. Understanding the psychosocial factors influencing the risky behaviour of young drivers. Transp Res Part F Traffic Psychol Behav 2009; 12:470-82. doi: 10.1016/j.trf.2009.08.003

4. Al-Lamki L. Life loss and disability from traffic accidents: It is imperative we all act now. Sultan Qaboos Univ Med J 2010; 10:1-5.

5. United Nations Road Safety Collaboration. Global plan for the decade of action for road safety 2011-2020. From: www.who. int/roadsafety/decade_of_action/plan/en/ Accessed: Jun 2017.

6. Bates LJ, Allen S, Armstrong K, Watson B, King MJ, Davey J. Graduated driver licensing: An international review. Sultan Qaboos Univ Med J 2014; 14:e432-41.

7. Curry AE, Garcia-España JF, Winston FK, Ginsburg K, Durbin DR. Variation in teen driver education by state requirements and sociodemographics. Pediatrics 2012; 129:453-57. doi: 10.1542/ peds.2011-2303.

8. Mayhew DR. Driver education and graduated licensing in North America: Past, present, and future. J Safety Res 2007; 38:229-35. doi: 10.1016/j.jsr.2007.03.001

9. Al-Matawah JA. An investigation of driver attitudes towards road safety in Kuwait. PhD Thesis, 2008, University of Southampton, Southampton, UK.

10. Jawi ZM, Deros B M, Osman MR, Awang A. A systemic overview on driver training and driver licensing system in Malaysia. Proceedings Conference ASEAN Road Safety 2015; 185-91.

11. Tronsmoen T. Differences between formal and informal practical driver training as experienced by the learners themselves. Transp Res Part F Traffic Psychol Behav 2011; 14:176-88. doi: 10. 1016/j.trf.2010.11.009.

12. Gregersen NP. Systematic cooperation between driving schools and parents in driver education: An experiment. Accid Anal Prev 1994; 26:453-61. doi: 10.1016/0001-4575(94)90036-1.

13. Jacobsohn L, García-España JF, Durbin DR, Erkoboni D, Winston FK. Adult-supervised practice driving for adolescent learners: The current state and directions for interventions. J Safety Res 2012; 43:21-8. doi: 10.1016/j.jsr.2011.10.008.

14. Nyberg A, Gregersen NP, Wiklund M. Practicing in relation to the outcome of the driving test. Accid Anal Prev 2007; 39:159-68. doi: 10.1016/j.aap.2006.06.015.

15. Hatakka M, Keskinen E, Gregersen NP, Glad A, Hernetkoski K. From control of the vehicle to personal self-control: Broadening the perspectives to driver education. Transp Res Part F Traffic Psychol Behav 2002; 5:201-155. doi: 10.1016/S1369-8478(02) 00018-9. 
16. Molina JG, García-Ros R, Keskinen E. Implementation of the driver training curriculum in Spain: An analysis based on the Goals for Driver Education (GDE) framework. Transp Res Part F Traffic Psychol Behav 2014; 26:28-37. doi: 10.1016/j.trf. 2014.06.005.

17. Passmore J, Mortimer L. The experience of using coaching as a learning technique in learner driver development: An IPA study of adult learning. Int Coach Psychol Rev 2011; 6:33-45.

18. Zakrajsek JS, Shope JT, Greenspan AI, Wang J, Bingham CR, Simons-Morton BG. Effectiveness of a brief parent-directed teen driver safety intervention (checkpoints) delivered by driver education instructors. J Adolesc Health 2013; 53:27-33. doi: 10.1016/j.jadohealth.2012.12.010.

19. Classen S, Krasniuk S, Knott M, Alvarez L, Monahan M, Morrow S, et al. Interrater reliability of Western University's on-road assessment. Can J Occup Ther 2016; 83:317-25. doi: $10.1177 / 0008417416663228$.

20. Ott BR, Festa EK, Amick MM, Grace J, Davis JD, Heindel WC. Computerized maze navigation and on-road performance by drivers with dementia. J Geriatr Psychiatry Neurol 2008; 21:18-25. doi: 10.1177/0891988707311031.

21. Aslaksen PM, Ørbo M, Elvestad R, Schäfer C, Anke A. Prediction of on-road driving ability after traumatic brain injury and stroke. Eur J Neurol 2013; 20:1227-33. doi: 10.1111/ene. 12172.

22. Wood JM, Worringham C, Kerr G, Mallon K, Silburn P. Quantitative assessment of driving performance in Parkinson's disease. J Neurol Neurosurg Psychiatry 2005; 76:176-80. doi: 10.1136/ jnnp.2004.047118.

23. Kübler TC, Kasneci E, Rosenstiel W, Heister M, Aehling K, Nagel K, et al. Driving with glaucoma: Task performance and gaze movements. Optom Vis Sci 2015; 92:1037-46. doi: 10.1097/OPX.000 0000000000702

24. Fox GK, Bashford GM, Caust SL. Identifying safe versus unsafe drivers following brain impairment: The Coorabel Programme. Disabil Rehabil 1992; 14:140-5. doi: 10.3109/09638289209165850.

25. Kalamaras MA, Rando A, Pitchford DG. Driving plastered: Who does it, is it safe and what to tell patients. ANZ J Surg 2006; 76:439-41. doi: 10.1111/j.1445-2197.2006.03762.x.

26. Akerstedt T, Hallvig D, Anund A, Fors C, Schwarz J, Kecklund G. Having to stop driving at night because of dangerous sleepiness: Awareness, physiology and behaviour. J Sleep Res 2013; 22:380-8. doi: 10.1111 /jsr. 12042

27. Almberg $M$, Selander $H$, Falkmer $M$, Vaz S, Ciccarelli $M$ Falkmer T. Experiences of facilitators or barriers in driving education from learner and novice drivers with ADHD or ASD and their driving instructors. Dev Neurorehabil 2017; 20:59-67. doi: 10.3109/17518423.2015.1058299.

28. Lamers CT, Ramaekers JG. Visual search and urban driving under the influence of marijuana and alcohol. Hum Psychopharmacol 2001; 16:393-401. doi: 10.1002/hup.307.

29. Taylor JE, Deane FP, Podd JV. Driving fear and driving skills: Comparison between fearful and control samples using standardised on-road assessment. Behav Res Ther 2007; 45:805-18. doi: 10.1016/j.brat.2006.07.007.
30. Lage M Jr, Filho MG. Variations of the kanban system: Literature review and classification. Int J Prod Econ 2010; 125:13-21. doi: 10.1016/j.ijpe.2010.01.009.

31. Hachicha W, Ghorbel A. A survey of control-chart patternrecognition literature (1991-2010) based on a new conceptual classification scheme. Comput Ind Eng 2012; 63:204-22. doi: 10.10 16/j.cie.2012.03.002.

32. Oviedo-Trespalacios $\mathrm{O}$, Haque $\mathrm{MM}$, King $\mathrm{M}$, Washington $\mathrm{S}$. Understanding the impacts of mobile phone distraction on driving performance: A systematic review. Transp Res Part C Emerg Technol 2016; 72:360-80. doi: 10.1016/j.trc.2016.10.006.

33. Boccara V, Delhomme P, Vidal-Gomel C, Rogalski J. Development of student drivers' self-assessment accuracy during French driver training: Self-assessments compared to instructors' assessments in three risky driving situations. Accid Anal Prev 2011; 43:1488-96. doi: 10.1016/j.aap.2011.02.029.

34. Boccara V, Delhomme P, Vidal-Gomel C, Rogalski J. Time course of driving-skill self-assessments during French driver training. Accid Anal Prev 2011; 43:241-6. doi: 10.1016/j.aap.2010.08.016.

35. Roelofs EC, Bolsinova M, Verschoor A, Vissers JA. Development and evaluation of a competence-based exam for prospective driving instructors. J Traffic Transp Eng 2015; 3:147-57. doi: 10. 17265/2328-2142/2015.03.003.

36. Arnau-Sabatés L, Sala-Roca J, Jariot-Garcia M. Emotional abilities as predictors of risky driving behavior among a cohort of middle aged drivers. Accid Anal Prev 2012; 45:818-25. doi: 10.1016/j.aap.2011.07.021.

37. Lajunen T, Summala H. Can we trust self-reports of driving? Effects of impression management on driver behaviour questionnaire responses. Transp Res Part F Traffic Psychol Behav 2003; 6:97-107. doi: 10.1016/S1369-8478(03)00008-1.

38. Austers I, Renǵe V, Škilters J. Driving instructors are not much better (at least sometimes) in explaining driving safety than ordinary drivers. Mediterr J Soc Sci 2015; 6:416-23. doi: $10.5901 / \mathrm{mjss} .2015 . v 6 n 2 s 1 p 416$

39. Treffner P, Barrett R, Petersen A. Stability and skill in driving. Hum Mov Sci 2002; 21:749-84. doi: 10.1016/S0167-9457(02) 00168-9.

40. Katila A, Keskinen E, Hatakka M. Conflicting goals of skid training. Accid Anal Prev 1996; 28:785-9. doi: 10.1016/S00014575(96)00045-0.

41. Boccara V, Vidal-Gomel C, Rogalski J, Delhomme P. A longitudinal study of driving instructor guidance from an activityoriented perspective. Appl Ergon 2015; 46:21-9. doi: 10.1016/j. apergo.2014.06.001.

42. Rismark M, Sølvberg AM. Effective dialogues in driver education. Accid Anal Prev 2007; 39:600-5. doi: 10.1016/j.aap.2006.10.008.

43. De Stefani E, Gazin AD. Instructional sequences in driving lessons: Mobile participants and the temporal and sequential organization of actions. J Pragmat 2014; 65:63-79. doi: 10.1016 /j.pragma.2013.08.020.

44. Lee DN. A theory of visual control of braking based on information about time-to-collision. Percept 1976; 5:437-59. 